Case Reports
in Dermatology

\title{
Cutaneous Myiasis Caused by Chrysomya megacephala in an Infant with Psoriasis Vulgaris
}

\author{
Siripan Sangmala ${ }^{a}$ Kumpol Aiempanakit ${ }^{a}$ Puttichart Khantee $^{b}$ \\ Theerakamol Pengsakul ${ }^{c}$ \\ aDivision of Dermatology, Department of Internal Medicine, Faculty of Medicine, Prince of \\ Songkla University, Hat Yai, Thailand; 'bivision of Infectious Diseases, Department of \\ Pediatrics, Faculty of Medicine, Prince of Songkla University, Hat Yai, Thailand; 'Faculty of \\ Medical Technology, Prince of Songkla University, Hat Yai, Thailand
}

\section{Keywords}

Myiasis · Maggot · Psoriasis · Infant · Skin

\section{Abstract}

Cutaneous myiasis is an infestation of the skin by fly larvae, which usually occurs in adults. We present a case of cutaneous myiasis caused by Chrysomya megacephala in a 3-month-old infant with psoriasis vulgaris. In this case report, we highlight the clinical, histopathologic, taxonomic identification, and treatment of cutaneous myiasis occurring in psoriatic skin.

(C) 2020 The Author(s)

Published by S. Karger AG, Basel

\section{Introduction}

Myiasis is an infestation of living tissue by fly larvae of the order Diptera [1]. Cutaneous myiasis can be subdivided into two main clinical subtypes, furuncular and wound myiasis [2]. Most of the cases are reported in adults and rarely in children [3]. A similar case was reported in which the larva penetrated the brain of a 5-month-old infant resulting in the demise of the patient [4]. We report a case of cutaneous myiasis caused by Chrysomya megacephala in an Asian infant with psoriasis vulgaris. 


\section{Case Reports in Dermatology}

Case Rep Dermatol 2020;12:249-254

DOI: $10.1159 / 000512709$

C 2020 The Author(s). Published by S. Karger AG, Basel www.karger.com/cde

Sangmala et al:: Cutaneous Myiasis in Infant Psoriasis

Case Report

A 3-month-old Thai girl presented with a 3-week history of generalized skin rash and developed a lump on the scalp after presenting with the primary rash for 2 weeks. Her grandmother had a history of psoriasis vulgaris, but she had no history of atopy in her family. Physical examination showed yellowish-brown crust and scale on an erythematous patch on the scalp, eyebrows, and ears and generalized, erythematous scaly plaques on the trunk (Fig. 1a) and extremities. The scalp showed a punctate wound at the vertex (Fig. 1b), containing many maggots (Fig. 1c, d). The scalp wound was debrided, and skin biopsy studies were performed. Dermatopathology showed typical psoriasis vulgaris at the epidermis and maggots in the subcutis (Fig. 2a-c). We sent the maggots for taxonomic identification by the Faculty of Medical Technology, Prince of Songkla University (Dr. Pengsakul). Worm size was $9 \mathrm{~mm}$ (Fig. 3a). The posterior spiracle (Fig. 3b), hook (Fig. 3c), and adult flies (Fig. 3d) developing from the maggots were identified as $C$. megacephala.

The diagnosis was furuncular myiasis caused by $C$. megacephala with underlying psoriasis vulgaris. Treatment involved manual removal of the larvae and 2 doses of oral ivermectin $200 \mu \mathrm{g} / \mathrm{kg} / \mathrm{dose}$. The latter treatment was started because the lesions contained a large number of worms which were difficult to manually remove. Her lesion improved without any adverse events from oral ivermectin.

\section{Discussion}

Furuncular myiasis is the most common form of primary cutaneous myiasis, and Cordylobia anthropophaga is the most common agent [1]. We report the first case of furuncular myiasis caused by C. megacephala, commonly known as the oriental latrine fly, in an infant with psoriasis. This fly also causes substantial economic problems in the Asia Pacific and Africa, where sun-drying is the primary method for preserving fish [5]. The first report of human myiasis caused by $C$. megacephala was in Thailand; however, this case was detected postmortem [6].

Risk factors for cutaneous myiasis are poor hygiene with low socioeconomic status [7]. The complication of cutaneous myiasis is a secondary bacterial infection. It can penetrate the brain via incompletely ossified bone of the skull, particularly in an infant [4]. In this case report, the possible association between psoriasis and cutaneous myiasis explained by an infant developed psoriatic rash and occurring secondary cutaneous myiasis. The patient had a strong familial history of psoriasis and set generalized skin rash on the whole body before maggot infestations of the scalp. However, psoriasis often occurs provoked by infections and it is usually relatively resistant to a secondary infection. Previous reports proposed secondary infection of maggot on the children scalp resulting in traumatic psoriatic plaque [8, 9].

Treatment of cutaneous myiasis include occlusion, manual removal of the larvae and larvicides $[2,3,10]$. In the pediatric population, there is no specific standard guideline treatment [11]. Occlusion and surgical intervention are recommended options. Ivermectin is not recommended in young children $(<5$ years of age or $<15 \mathrm{~kg}$ ) because of insufficient evidence [12]. However, a recent review showed ivermectin was well tolerated in the children without any evidence of severe or long-term side effects [13]. In this case, we manually removed the larvae and added oral ivermectin to the treatment. We treated with ivermectin because of inadequate treatment from surgical intervention. Adverse effects associated with ivermectin use include cutaneous and systemic effects such as rash, pruritus, myalgia, abdominal pain, 


\section{Case Reports in Dermatology}

hypotension, and dizziness $[10,12]$. In this case, there were no adverse reactions noted secondary to ivermectin.

In conclusion, we report this case to enhance recognition for the prevention of cutaneous myiasis and to provide adequate taxonomic identification for proper diagnosis and treatment when there is a high level of suspicion.

\section{Statement of Ethics}

Written informed consent to publish this case (including images) was obtained from the patient's parents. The research was conducted ethically in accordance with the World Medical Association Declaration of Helsinki and was approved by the Research Ethics Committee, Faculty of Medicine, Prince of Songkla University (REC. 62-320-14-1).

\section{Conflict of Interest Statement}

There are no conflicts of interest.

\section{Funding Sources}

None.

\section{Author Contributions}

S.S. drafted the manuscript and K.A. revised it critically for important intellectual content. S.S., K.A., P.K. and T.P. were involved in the conception of this case report and gave final approval of the version published.

\section{References}

1 Bernhardt V, Finkelmeier F, Verhoff MA, Amendt J. Myiasis in humans-a global case report evaluation and literature analysis. Parasitol Res. 2019 Feb;118(2):389-97.

2 Burkhart CN, Burkhart CG, Morrell DS. Infestations. In: Bolognia JL, Schaffer JV, Cerroni L, editors. Dermatology. 4th ed. China: Elsevier; 2018. pp. 1503-15.

3 Calvopina M1 Ortiz-Prado E. Castañeda B, Cueva I, Rodriguez-Hidalgo R, Cooper PJ. Human myiasis in Ecuador. PLoS Negl Trop Dis. 2020;14:e0007858.

4 Rossi MA, Zucoloto S. Fatal cerebral myiasis caused by the tropical warble fly, Dermatobia hominis. Am J Trop Med Hyg. 1973 Mar;22(2):267-9.

5 Wall R, Howard JJ, Bindu J. The seasonal abundance of blowflies infesting drying fish in south-west India. J Appl Ecol. 2001;38(2):339-48.

6 Sukontason KL, Narongchai P, Sripakdee D, Boonchu N, Chaiwong T, Ngern-Klun R, et al. First report of human myiasis caused by Chrysomya megacephala and Chrysomya rufifacies (Diptera: Calliphoridae) in Thailand, and its implication in forensic entomology. J Med Entomol. 2005 Jul;42(4):702-4.

7 Fernandes LF, Pimenta FC, Fernandes FF. First report of human myiasis in GoiáS state, Brazil: frequency of different types of myiasis, their various etiological agents, and associated factors. J Parasitol. 2009 Feb;95(1):32-8.

8 Mariwalla K, Langhan M, Welch KA, Kaplan DH. Cutaneous myiasis associated with scalp psoriasis. J Am Acad Dermatol. 2007 Aug;57(2 Suppl):S51-2. 


\section{Case Reports in Dermatology}

\begin{tabular}{l|l}
\hline Case Rep Dermatol 2020;12:249-254 \\
\hline DOI: 10.1159/000512709 & $\begin{array}{l}\text { C } 2020 \text { The Author(s). Published by S. Karger AG, Basel } \\
\text { www.karger.com/cde }\end{array}$ \\
\hline
\end{tabular}

Sangmala et al.: Cutaneous Myiasis in Infant Psoriasis

9 Pereyra-Rodríguez JJ, Bernabeu-Wittel J, Conejo-Mir MD, Ruiz-Pérez de Pipaón M, Conejo-Mir J. Treatment of cutaneous myiasis associated with scalp psoriasis in a 13-year-old girl with oral ivermectin. J Am Acad Dermatol. 2010 Nov;63(5):908-9.

10 Francesconi F, Lupi O. Myiasis. Clin Microbiol Rev. 2012 Jan;25(1):79-105.

11 Solomon M, Lachish T, Schwartz E. Cutaneous Myiasis. Curr Infect Dis Rep. 2016 Sep;18(9):28.

12 Thomas C, Coates SJ, Engelman D, Chosidow O, Chang AY. Ectoparasites: scabies. J Am Acad Dermatol. 2020 Mar;82(3):533-48.

13 Wilkins AL, Steer AC, Cranswick N, Gwee A. Question 1: is it safe to use ivermectin in children less than five years of age and weighing less than $15 \mathrm{~kg}$ ? Arch Dis Child. 2018 May;103(5):514-9.
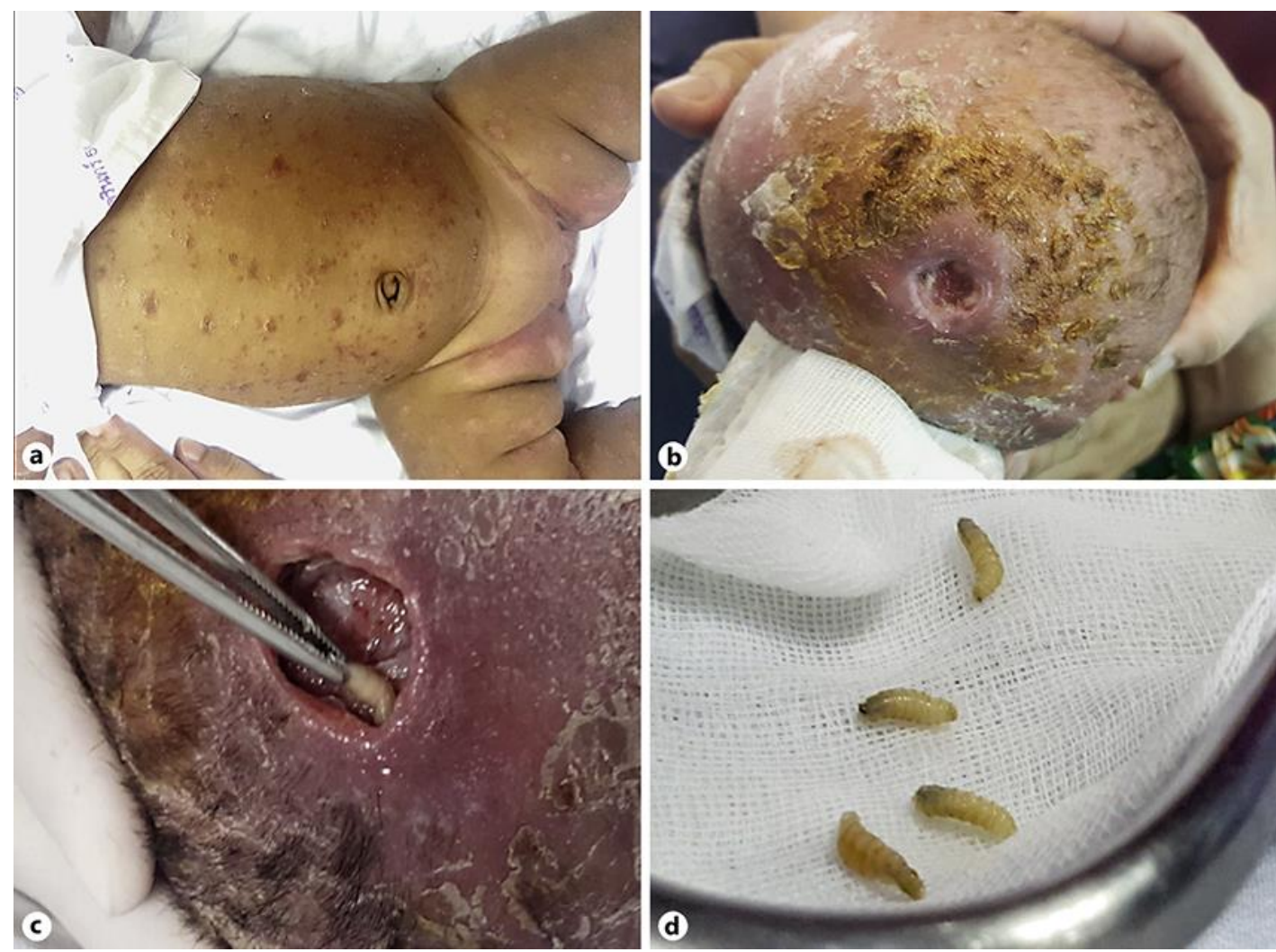

Fig. 1. Clinical photographs. a Skin rash on the trunk and extremities. b Skin lesions and ulcer on the scalp. c Maggot removed from the wound. $\mathbf{d}$ Larvae. 


\section{Case Reports in Dermatology}

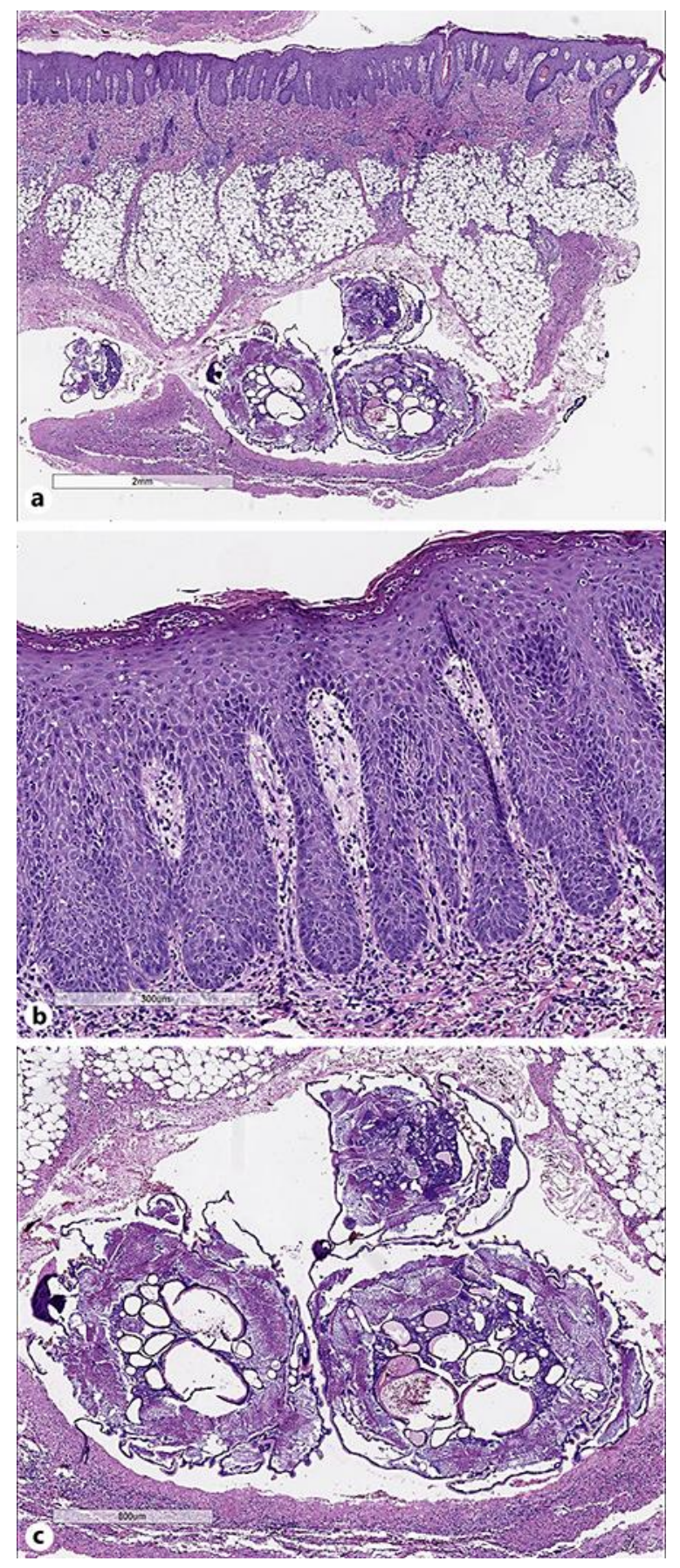

Fig. 2. Dermatopathology. a Low magnification showing psoriasiform at the epidermis and maggots in the subcutis. b High magnification of the epidermis showing psoriasiform hyperplasia, infiltration of neutrophils within the epidermis, and spongiform pustule of Kogoi. c High magnification of the subcutis presenting with maggots. 


\section{Case Reports in Dermatology}
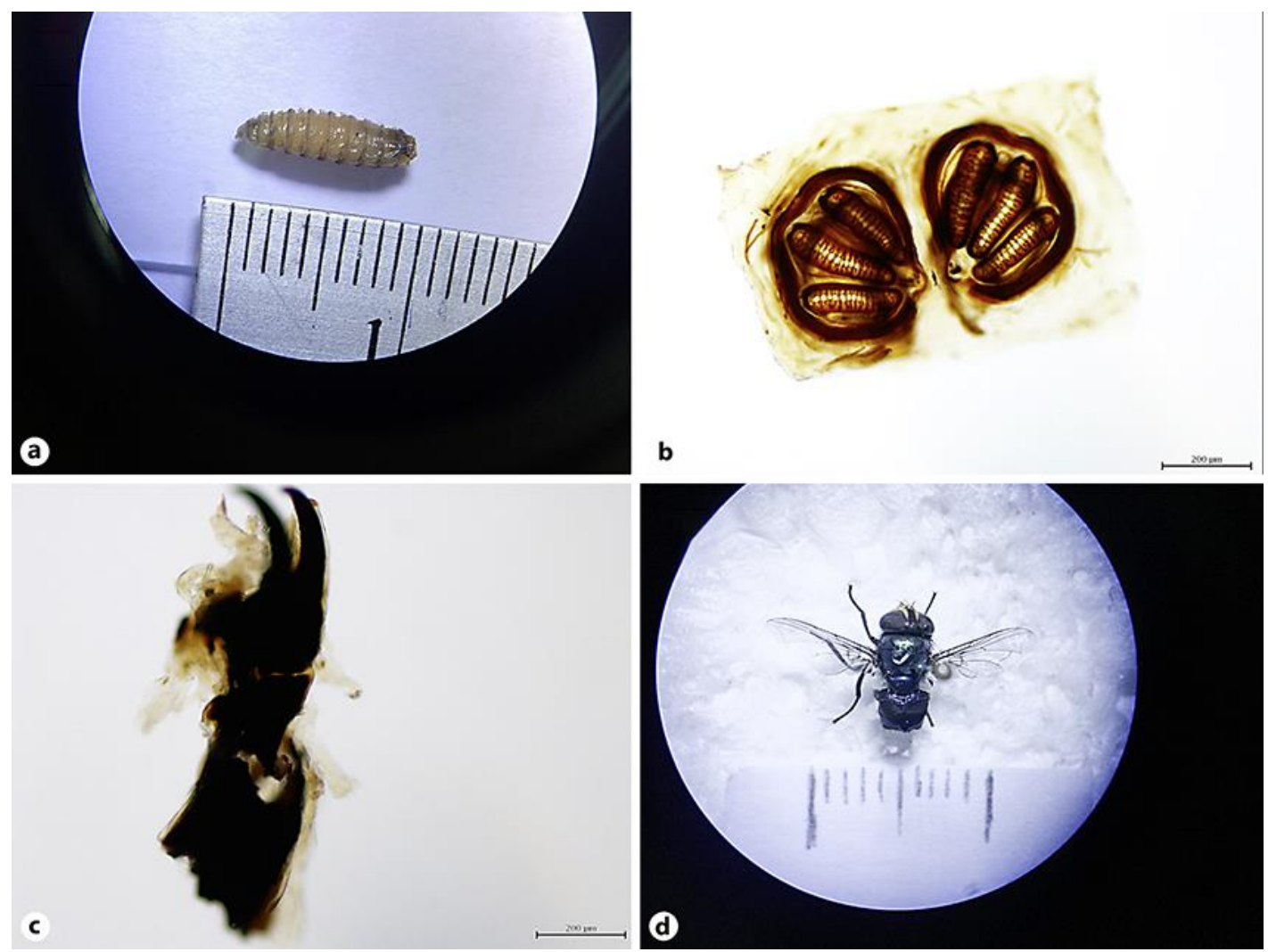

c

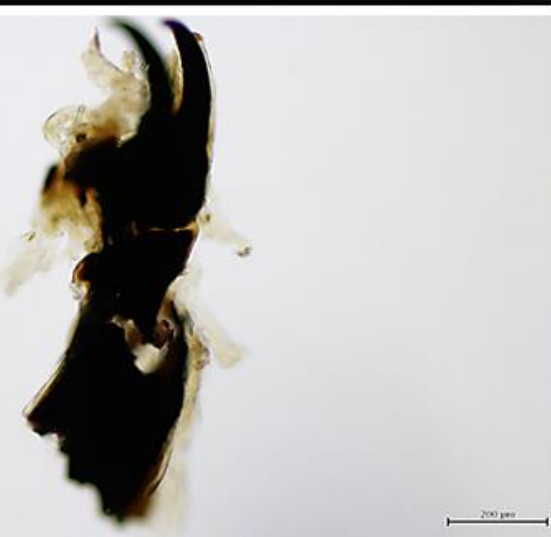

Fig. 3. Taxonomic identification with Chrysomya megacephala. a Size of the worm. b Posterior spiracle. c Hook. d Adult fly. 